\title{
NĪSHĀPŪRĪ SCHOLARS IN THE FORMATION OF SUNNĪ SCHOLARSHIP IN THE ELEVENTH CENTURY
}

\author{
Mohammad Syifa Amin Widigdo \\ Universitas Muhammadiyah Yogyakarta, Yogyakarta, Indonesia \\ email:syifamin@umy.ac.id
}

\section{Abstract}

The role of Nishäpuri medieval scholars in the tenth-eleventh century in the formation of Sunni orthodoxy has been rarely discussed. The existing scholarship focuses primarily on the local bistory of Nishäpür and otherparts of eastern Muslim world or emphasizes more on the contribution of Baghdadi scholars in the light of the formation of Sunni legal schools, which in turn is deemed as Sunni orthodoxy, than their counterpart in Nishäpür and other cities in the east. Therefore, this paper attempts to show how Muslim scholars from Nishäpür contributed to the advancement of Sunni scholarship in the fifth/ eleventh century through a closer study of intellectual strategies developed and employed by Nishäpuiri scholars to cope with their local challenges. They built intellectual networking and attempted to integrate legal and theological scholarship in Islamic scholarship to deal with their local problems, which interestingly shaped their distinctive contribution in the light of Sunni scholarship tradition. By means of this attempt of intellectual networking and harmonizing legal scholarship (figh) and theological scholarship (kalām), they were not only able to tackle local problems but also equipped with intellectual means to push doctrinal boundaries within Sunni scholarship in the fifth/ eleventh century.

Peran ilmuwan Nishäpür abad pertengahan dalam pembentukan ortodoksi Sunni di abad 10 - 11 masehi masih jarang dibahas. Kebanyakan sarjana yang ada lebih banyak memperbatikan sejarah lokal Nishäpür dan bagian 
lain dari dunia muslim di timur atau menekankan pada kontribusi sarjana asal Baghdäd dimasa puncak formasi mazhab Sunni, dimana lebih sering dianggap sebagai Sunni ortodoks daripada kawan mereka di Nishäpür dan kota lain di timur. Oleh karena itu, artikel ini berusaha untuk menunjuk.kan bahwa sarjana muslim dari Nishäpür berkontribusi pada pengembangan pemikiran Sunni di abadpertengahan melalui kajian mendalam pembangunan strategis intelektual dan karya dari sarjana Nishäpür dalam mengatasi tantangan lokal. Mereka membangun jaringan intelektual dan berusaha mengintegrasikan bukum dan teologi dalam Islam dengan masalab lokalitas, yang mana kontribusi khasnya berpengaruh dalam tradisi teologi Sunni. Melalui usahanya ini, jaringan intelektual dan harmonisasi figh dan kalam, mereka tidak hanya mengatasi persoalan lokal tetapi juga melengkapinya dengan seperangkat intelektual untuk. mendorong batas-batas dalam tradisi Sunni di abad pertengahan.]

Keywords: Nīshāpūr, Sunnī orthodoxy, Ismā̄îlī Shī'a, kalām, fiqh, Shāfî̄i, Hanafî.

\section{A. Introduction}

The power of the 'Abbāsid caliphate in the tenth to early eleventh century was waning when at the same time Shīi ${ }^{`}$ political dynasties were triumphant in most of the Islamic world. Although the Umayyad dynasty in Spain (756-1039) was in power far to the west and some Sunnī dynasties like the Sāmānids (874-999) and Ghaznavids (9761186) controlled Muslim lands in the east, Shīi political dynasties like the Fāṭimid, Qarmāṭid, Hamdānid, and Buwayhid were prominent and dominant in the central lands of the Islamicate world. The Shî'i Ismāa 1 il Fāṭimid Imāmate (969-1171) had ruled in Egypt and North Africa and the Shî̀i Imāmî Buwayhid dynasty (934-1055) ruled in 'Irāq and some Western Iranian regions. It is therefore not surprising when Marshall G.S. Hodgson designated this century as "the Shīi century" and more

1 Marshall G.S. Hodgson, The Venture of Islam: Conscience and History in a World Civilisation, vol. 1: The Classical Age of Islam (Chicago: University of Chicago Press, 1974), p. 36. The Shī'a is a religious group within Islam who believes that 'Alī b. Abī Țālib (d. 40/661) is the successor of the Prophet Muhammad (d. 13/632) as the leader of the Muslim community. After the death of 'Alī, the leadership is handed down to 'Alìs 
specifically Louis Massignon called this period the "Ismā'îli century" of Islam (le siècle ismaëlien de l'Islam). ${ }^{2}$

When the Saljūq bands overthrew Shì ì Buwayhid rule in Baghdād in 447/1055, their main objective was to hold 'Irāq as a bastion against the Ismā '̂̀ $1 \bar{l}$ Fātimids and their satellites in Syria and al-Jazìra (i.e. a region that covers a crossroad linking 'Irāq, Anatolia, Syria, Armenia, and Iran). ${ }^{3}$ Soon after the Buwayhids were ousted, the Saljūqs established Sunnī institutions in order to face the challenges from the missionaries of the opposing groups, such as the Karrāmīs ${ }^{4}$ and Ismā îlìs. ${ }^{5}$ These institutions introduced a new madrasa system and trained students to be scholars, qä $\bar{l} \bar{s}$, and administrators. The first madrasa, namely the madrasa al-Nižamì̄ya, was built in Nīshāpūr in 450/1058 and the larger madrasa al-Niżamìya was also established in Baghdād in 459/1067. Interestingly, these madrasas in the end were not only able to hamper the influence

descendants. The term "Shic i’" refers to a person or a group of people who belongs to Shi'‘ group. For further information, see Moojan Momen, An Introduction to Shi i Islam: The History and Doctrines of Twelver Shi'ism (New Haven: Yale University Press, 1987).

2 Louis Massignon, "Mutanabbi, devant le Siecle Ismaelien de l'Islam", in $\mathrm{Al}$ Mutanabbi. Recueil Publié a l'Occasion de son Millénaire (Beirut: Institut Francais de Damas, 1936), p. 1. The Ismā̄îliss is a branch of Shī'a Islam believing that the right sixth Imām is the Ismā'îl b. Ja'far al-Ṣādiq (d. 100/719), not his brother Mūsā b. Ja'far al-Ṣādiq (d. 183/799), and the seventh imām is the son of Ismā'ill, namely Muhammad b. Ismā'îl (d.128/746). For this reason, a group of Shi'a community who believes that Ismā'îl is the seventh Imām of Shī'a is called Ismā'îlī or the seveners. One of their main religious teachings is an emphasis on the esoteric (bätin) of Islam. For a further reading about Ismā'ilìn, see Farhad Daftary, The Isma'ilis: Their History and Doctrines (Cambridge: Cambridge University Press, 2007).

3 C.E. Bosworth, "The Political and Dynastic History of the Iranian World (A.D. 1000-1217)", in The Cambridge History of Iran, vol. 5: The Saljuq and Mongol Periods, ed. by J.A. Boyle (Cambridge: Cambridge University Press, 1968), p. 43.

4 The Karrāmīs are a group of people who follows a religious group in Nīshāpūr named Karrāmīya. The group was founded by Abū 'Abdullāh Muhammad b. Karrām (d. 255/869), whose teachings emphasized on mystical and literal interpretation of theology so that their opponents accused them of anthropomorphists. See Margaret Malamud, "The Politics of Heresy in Medieval Khurasan: The Karramiyya in Nishapur", Iranian Studies, vol. 27, no. 1/4 (1994), pp. 37-51; C.E. Bosworth, "The Rise of the Karrāmīyah in Khurasan", in The Medieval History of Iran, Afghanistan, and Central Asia, ed. by C.E. Bosworth (London: Variorum Reprint, 1977), pp. 5-14.

${ }^{5}$ Hodgson, The Venture of Islam, 1: The Classical Age of Islam: p. 47. 
of Ismā 'îli missionaries but were also instrumental in fostering a "Sunnī Revival" in the main lands of Islam. The lands of Islam ranging from the Mediterranean Sea to Central Asia were reunited under Sunnī-Islam ${ }^{7}$

6 “The Sunnī Revival" refers to George Makdisi's account on the advancement of traditionalists' (ablal-hadith) triumph in the eleventh century after their initial victory over the rationalist movement (i.e. Mu tazilis) in the ninth century through traditionalism of al-Shāfíi (d. 204/820) and Ibn Hanbal (d. 241/855). After a slight defeat in the tenth century, according to Makdisi, the Sunnī traditionalists revived and prevailed again in the eleventh century through different ways and forms. For example, the creed of the caliph al-Qādir (d. 422/1031) that affirmed and enforced a traditional stance of Islam, the policy of Tughril Beg that persecuted the Ash 'arīs, Nizām al-Mulk's madrasas that taught only Islamic law, and Abū Hāmid al-Ghazālī who only taught Islamic law in the Nizāamìya of Baghdād. For a further reading, see George Makdisi, "The Sunnī Revival", in History and Politics in Eleventh-Century Baghdad, ed. by George Makdisi (London: Variorum, 2010), pp. 155-68. Although I disagree with Makdisi's depiction of the traditionalist victory in the eleventh century, the term "Sunni Revival" is still useful to depict the departure of the Muslim world from what so-called "Shī' 1 or Ismā 'îlì Century" to the period when the Sunnī Saljūq Sultanate took control the capital caliphate in Baghdād, governed the majority of Muslim lands, and established Sunnī institutions of learning (madrasas) in the eleventh century.

7 Sunnī Islam is a translation of the Arabic term Abl al-Sunna wa al-Jamā'a (People of the Prophet's Sunna and the Community). The designation of the term varies depending on the context. First, the Sunnī could mean a group of Muslims who are not Shī '⿳亠 therefore they do not believe in the appointment of 'Alī b. Abī Taalib as the sole successor of the Prophet Muhammad and do not recognize the leadership (imama) of 'Alì's descendants. Second, the term Sunnī could also refer to a group of Muslims who rely more on the Sunna (practice) or Hadith (report) from the Prophet instead of an authority of 'aql (speculative reasoning that usually used by theologians). Third, Sunnī Islam also designates $\operatorname{shari~}^{-6} a$ (legal)-minded school of thought (fuqahā') that differ from the mystical-minded school of thought (i.e. $S$ üfi). For more detail information, see Hodgson, The Venture of Islam, 1: The Classical Age of Islam, pp. 276-9. In this article, the term Sunnī Islam is used inclusively to refer to non-Shī' a group, people of tradition, or legal-minded people. However, when the Sunni term is mentioned in the context of religious scholarship of the ninth and tenth centuries, it mainly denotes a group of people who advocated or followed certain Islamic legal schools that emerged at that time, such as Ḥanafī, Mālikī, Shāfi '̇i, and Hanbalī schools. For more detail information, see Richard C. Martin, Islamic Studies: A History of Religions Approach (New Jersey: Prentice Hall, 1996), pp. 10-1. As for the historical emergence of these schools, see Christopher Melchert, The Formation of the Sunni Schools of Law, 9th-10th Centuries C.E. (Leiden: E.J. Brill, 1997). 
dominion. ${ }^{8}$

However, the supposed "Sunnī revival" was not smoothly achieved. There were internal social-intellectual dynamics and struggles within the Saljūq's administrative regions that led to the resurgence of Sunnī Islam. The threat of Ismāi îli missionaries, the emergence of heretical and mystical groups, sectarian conflicts in major cities like Nīshāpūr, and networking among Sunnī scholars in fact contribute significantly to the maturity of Sunnī orthodoxy. ${ }^{9}$

This article, therefore, will not discuss "Sunnī revival" in a broad sense but will focus on the role of Sunnī scholars in such revival. By looking closely at the city of Nīshāpūr in which religious scholars attempted to institutionalize religious disagreements and conflicts, ${ }^{10}$ this paper will discuss how Nīshāpūrī scholars ${ }^{11}$ achieved a high level

8 Richard N. Frye, The Golden Age of Persia (New York: Barnes \& Noble Books, 1975), p. 226.

9 Although the application of the term "orthodoxy (correct belief)" in Islamic context is contested by scholars of Islam, considering another term, which is "orthopraxy (correct practice)", might be more accurate to denote "the correct belief and practice" in Islam, I use this term to denote what Sunni group considers "correct" belief and practice up to the tenth century. In this period, the Sunni orthodoxy was associated with the traditional teachings of what Marshal Hodgson might call the "Sharī'a-minded people." Their teachings, represented by al-Shāfi'î's formulation of the Prophetic Sunna in his legal epistemology and Ibn Hanbal's teaching of the uncreatedness of the Qur'an, had been repressed under the Mu tazili regime of Caliph al-Ma'mūn (d. 218 /833) in the early ninth century. However, in the second half of the ninth century onward, the teachings of the "Sharī a-minded people" started to prevail and became the mainstream of Sunnī-Islamic doctrines in the form of Shāfi 'ì, Hanbalī, Mālikī, and Hanafī schools. I argue that these legal schools, then, became "Sunnī orthodoxy" up to the tenth century because, in the following centuries, "Sunnī orthodoxy" was not only associated with Sunnī legal schools but theological and or mystical school as well. For a further reading of how a certain orthodoxy is formed and formulated, see Richard C. Martin and Abbas Barzegar, "Formations of Orthodoxy", in Rethinking Islamic Studies: From Orientalism to Cosmopolitanism Bruce B. Lawrence:, ed. by Carl W. Ernst and Richard C. Martin (South Carolina: University of South Carolina Press, 2010), pp. 179-202; Ma. Isabel Fierro (ed.), Orthodoxy and Heresy in Islam (Abingdon, Oxon; N.Y.: Routledge, 2014), pp. 257-74.

10 John Walbridge, God and Logic in Islam the Caliphate of Reason (Cambridge: Cambridge University Press, 2011), pp. 143-4.

11 Nīshāpūri scholars refer to the ulamā’ who are originally from Nīshāpūr, who are trained in Nīshāpūr, or who pursue a career in Nīshāpūr. 
of scholarship through their attempt in harmonizing, even integrating, religious sciences (mainly fiqh and kaläm). This discussion in fact will provide a closer look at the contribution of the eastern part of the medieval Muslim world to the advancement and maturity of Sunnī orthodoxy.

\section{B. Medieval Nīshāpūr: Potential Threats to Sunnī Establishment}

The medieval city of Nīshāpūr was one of four major cities in the province of Khurāsān in addition to Marw, Herāt, and Balkh. It was the largest and the most important metropolis in the eastern part of Iran on the Silk Road. Nīshāpūr furthermore connected Baghdād, the capital city of the 'Abbāsid caliphate, with the three major cities on Khurāsān to the east and, beyond them, with India and China. ${ }^{12}$ Not surprisingly Yāqūt al-Hamawī (d. 626/1229) in his geographical dictionary called Nīshāpūr "the gateway to the east". ${ }^{13}$ Nisshāpūr became an international trading center and prospered greatly in the tenth century until the early eleventh century, during Sāmānids rule until the end of the Saljūq period. ${ }^{14}$

The strategic geographical position of Nīshāpūr not only gave economic benefits to the city but also attracted people from different religions, including Arab-Muslims, to come and spread their beliefs. Before the coming of Islam, the people of the city were Zoroastrians, Jews, Christians, and Buddhists. Conversion to Islam came gradually and large-scale conversions occurred much later after the initial coming of the Arabs. ${ }^{15}$ Initially, according to Jamsheed Choksy, Muslim population concentrated in cities like Nīshāpūr and Herāt, away from non-Muslim population. In 665, Ziyād b. Sufyān (d. 53/673) as the governor of 'Irāq started to relocate Muslims to provincial areas such as Busht, southwest of Nīshāpūr, and Ustuva, northwest of Nīshāpūr. At this time, Marw had also a significant number of Muslim populations coming from Bașra and

${ }^{12}$ Jens Kroger, Nishapur: Glass of the Early Islamic Period (New York: Metropolitan Museum of Art, 1995), p. 9.

13 Charles K. Wilkinson, Nishapur: Some Early Islamic Buildings and Their Decoration (New York: Metropolitan Museum of Art, 1986), p. 38.

14 Kroger, Nishapur, p. 9.

15 Richard W. Bulliet, The Patricians of Nishapur: A Study in Medieval Islamic Social History (Cambridge: Harvard University Press, 1972), p. 15. 
Kūfa. In 725, the Umayyad governor of Khurāsān, Asad b. 'Abdullāh alQașrī (d. 120/738), brought sizable Muslim dwellers at Baruqan to Balkh as well, which made Muslim population in Balkh increasing. ${ }^{16}$ Around 738 , the chief dehgann (city inhabitants) in Herāt also converted to Islam. ${ }^{17}$ However, it did not mean that Muslim population became a majority at this time, especially in Nīshāpūr. By then year 739, Zoroastrians were still the majority under the leadership of Wahram Sagis. In 750, when 'Abbāsid came to power, about 8 percent of the urban population of Iran was Muslim. ${ }^{18}$ This number, Choksy writes, had reached 50 percent by the middle of the ninth century. ${ }^{19}$ At the end of the tenth century, the figure was staggering. The Muslim population in Iranian cities, including Nīshāpūr, was to around 80 percent. This was largely due to the mass "conversion of Zoroastrians - and some Jews, Christians, and Buddhists - between the eighth and tenth centuries". ${ }^{20}$ One of Karrāmī leaders, Abū Ya qūb Ishāq b. Maḥmashādh (d. 383/993), is said to have converted 5000 thousands of Zoroastrians, Christians, and Jews to Karrāmìya Islam through his eloquent preaching and evangelistic fervor in Nishāpūr. ${ }^{21}$ By the end of the eleventh century, the large majority of people in Nīshāpūr were Muslims, at least in urban areas. ${ }^{22}$

16 Jamsheed K. Choksy, Conflict and Cooperation: Zoroastrian Subalterns and Muslim Elites in Medieval Iranian Society (New York: Columbia University Press, 1997), p. 39.

17 Ibid., p. 82.

18 Richard W. Bulliet, Conversion to Islam in the Medieval Period (Cambridge: Harvard Univ Press, 1979), p. 44.

${ }^{19}$ Choksy, Conflict and Cooperation, p. 83.

${ }^{20}$ Ibid.

21 Bosworth, "The Rise of the Karrāmīyah in Khurasan", p. 7.

22 Bulliet, The Patricians of Nishapur, p. 15. However, with regard to majority of people who lived outside urban areas, we know little about their conversion and religiosity. We can only know that the conversion process in rural areas went slower so that not many of them, considering their big number, were willing to adopt Islam. See Richard W. Bulliet, Islam: The View From the Edge (New York: Columbia University Press, 1994), p. 77. We are also informed that the most active and attractive religious movement in rural areas was Karrāmìya. C.E. Bosworth mentions that the founder of Karrāmīya, Abū 'Abdullāh Muhammad b. Karrām (d. 255/869), actively preached his ascetic, literal, and anthropomorphist understanding, especially related to the reality of the punishment in the graveyard ("adhäb al-qabr), to the peasants, weavers, and other poor classes in rural areas. He gained popularity and followers from those lower classes of 
Muslims were interestingly not a single entity in Nīshāpūr. In addition to local groups like the Karrāmìya, there are two large Sunnī Islam groups, the Hanafîs ${ }^{23}$ and the Shāfi ${ }^{\prime}{ }^{24}{ }^{24}$ Their leaders, either through an election by Nīshāpūrī patricians or an appointment by the dynasty in power, ${ }^{25}$ filled key posts in the city ranging from a position of a qädì (judge), shaykh al-isläm (the spiritual head of Islam), khatīib (Friday sermon preacher), and $r a^{\prime}$ 's (mayor of the city). ${ }^{26}$ They also made centers of learning in their private houses, madrasas, or congregational mosques to maintain the continuity of Sunnī Islam in the city. ${ }^{27}$ However, the strength of the Sunnīs was vulnerable to external and internal factors. There were at least three factors that could challenge and threaten the authority of Sunnīs in Nīshāpūr: first, the missionary operation of the Ismā ${ }^{-i}$ liss; second, the existence of allegedly heretical and mystical groups; and third, a prolonged conflict between the Shāfíi and the Hanafì.

As mentioned above, the tenth to the very early eleventh centuries marked the so called Shî̀ century. The political domination of Shî'as, however, largely took place in the central and western parts of the Muslims under the Fățimids, the Buwayhids, the Qarmațids, and the Hamdānids dynasties. Eastern areas were still under the control of

society who were attracted to his messages and ascetic-pious way of life. See Bosworth, "The Rise of the Karrāmīyah in Khurasan", pp. 5-6.

23 The Hanafís are a group of people who follow a legal school called the Hanafí school, which was named after its founding jurist Abū Hanīfa (d. 150/767). The students of Bu Haniffa developed a method of deriving religious rulings and interpretations using principles taught by Abū Hanīfa, which was frequently considered more rational. The followers of the Hanafí school are called the Hanafis. However, in the context of Nìshāpūr, the Hanafîs were not only followers of the Hanafì legal school but also a political faction in the city which often competed with another faction of patricians, especially the Shāfi 'iss, for religious and political posts.

${ }^{24}$ The Shāfi 'is are the followers of the Shāfi 'î̀ legal school. This legal school was named after its founder Muhammad b. Idrīs al-Shāfí ${ }^{1}(204 / 820)$ by his students and followers who developed a more rigor method of deriving rulings and interpretations from religious sources based on principles taught by al-Shāfi $i$. Similar to the Hanafiss, the Shāfíns also played a role as a political faction in the context of Nīshāpūr in addition to their association with the Shāfi 'i legal school.

25 Bulliet, The Patricians of Nishapur, p. 64.

26 Ibid., pp. 62-9.

27 Ibid., p. 54. 
Sunnī Muslim authority, especially during the Sāmānids (819-999) and Ghaznavids periods (976-1186). Contemporary to Sāmānids and Ghaznavids that ruled in Nìshāpūr in tenth century, the major political power in western, central, and northern Iran was the Buwayhid dynasty during 934-1062 C.E. ${ }^{28}$ which initially belonged to the Zaydī ${ }^{29}$ but in a later period of their rule tended to lean towards the Imāmìya/the Ithnā 'Asharīya (the twelver Shī'a). ${ }^{30}$ However, the bulk of Iranian Muslims were still adherents of Sunnī Islam until after 907/1501, when Shāh

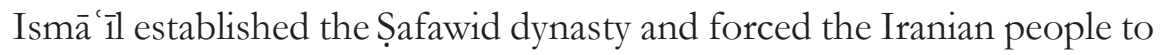
convert to the twelver Shī ism. ${ }^{31}$

28 David Morgan, Medieval Persia 1040-1797 (London: Pearson Education Limited, 1988), pp. 22-3.

29 This is the branch of Shī' a that recognized the son of the fourth imām Zayn al- 'Ābidīn (d. 95/713), namely Zayd b. Zayn al- 'Ābidīn (d. 125/743), as the fifth imām of Shī'a, instead of another son named Muḥammad al-Bāqir (d. 117/735). See Momen, An introduction to Shici Islam, p. 49.

30 The founder of the Buwayhids, 'Alī b. Būya (d. 338/949) and better known as Imād al-Dawla (the founder of the state), was originally from Daylam, an Iranian region on the south shore of the Caspian Sea. The Zaydī branch of Shī' a's missionaries came to this region and persuaded the people of Daylam (Daylamīs) to convert to Zaydī Shī'a in the second half of the third/ninth century. Therefore, Imäd al-Dawla and his successors were Zaydī-Shī a by tradition because the Daylamī were converted to Islam by the Zaydī $d_{a^{-}} i \bar{s}$. However, in a later period, the Buwayhids were leaning more towards the Imāmī Shī'a. See Heribert Busse, "Iran under the Būyids", in The Cambridge History of Iran, vol. 4: The Period from the Arab Invasion to the Saljuqs, ed. by Richard N. Frye (Cambridge: Cambridge University Press, 1975), p. 256. The Buwayhids' orientation towards the Imāmī Shî̀ a can be seen among other things from an extensive building at the shrines of the Seventh and the Ninth Imāms (these two Imāms are not recognized by the Zaydīs). Also, the possible reason for the Buwayhids to be more leaning towards the Imāmī Shī'a was that they were not the descendants of 'Alī b. Abì TTàlib, the first Imām of the Shì 'a. The Zaydī would have required them to install one of the descendants of 'Alī to be imàm (spiritual and political leader) when the Buwayhids were in power. However, after they came to power, they did not want to give a power to the real descendant of 'Alī. In this situation, the doctrine of the Imāmī Shī' a was politically more attractive to them because their twelfth imām (leader) Muhammad al-Mahdī was in occultation since 260/874. In the absence of the real imàm, al-Mahdī, the Buwayhids could act on his behalf. See Momen, An introduction to Shic Islam, pp. 75-6. Ibid., p. 161.

31 Morgan, Medieval Persia 1040-1797, p. 120. The process of conversion from Sunnīsm to twelver Shī ism was not an immediate, but it took another generation to be completed and successful. The twelver (Ithnā 'Asharīya) is the branch of Shī'a that 
The Ismā 'îlī Shī'ism was, therefore, certainly not a major political power in eastern Islam, especially in Iran, in the tenth to early eleventh century, nor was in a major population. Accordingly, the Fāțimid dynasty, whose official ideology was Ismā ${ }^{e} \bar{l} \bar{i}$ Shì ism and was very strong in Egypt and North Africa, sent Ismā î̀li missionaries $\left(d^{-} \bar{a}^{c} \bar{s}\right)^{32}$ to this regions, including Nīshāpūr. The purpose was not only to convert the Sunnī and

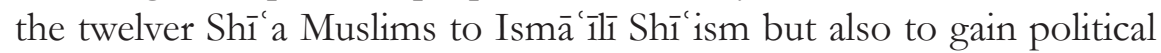
influence. Ismā̄îlism initially spread in the east like al-Jibāl, Khurāsān, and Transoxania regions through Arab dā $i$ s around 260/873-4. Later in the tenth century, the Ismā îlis established a headquarter of $d a^{6} w a$ (missionary) ${ }^{33}$ in Rayy that was led by such influential dā ${ }^{i}$ like Khalaf al-Hallāj, Ghiyāth from Kulayn, and Abū Hātim al-Rāzī. ${ }^{34}$ This da'wa operation subsequently reached cities in Khurāsān around 290-300/903913 through the efforts of Abū 'Abdullāh al-Khādim. ${ }^{35}$ Al-Khādim established himself in Nīshāpūr as the first chief dā He was then succeeded by other prominent missionaries such as Abū Sa 'ìd al-Sha 'rānī in 307/919, al-Husayn b. 'Alī al-Marwazì (the one who transferred the provincial seat of $d a^{6} w a$ from Nīshāpūr to Marw al-Rūdh

the imäms are not only limited to five (which was held by the Zaydīs) or seven (which was held by the Ismā îlīis) but up to twelve imäms. The last imàm, namely Muhammad al-Mahdī, was deemed to be in occultation and expected to return near to the end of the day. See Momen, An Introduction to Shic Islam.

$32 D \bar{a}^{-} \bar{i}$ (its original plural form is $d u^{\varsigma} \bar{a}$, but here I keep the term " $d \bar{a}^{\boldsymbol{c}} \bar{\imath}$ " plus the suffix "s" to denote the plural form) is literally used to call someone who summons.

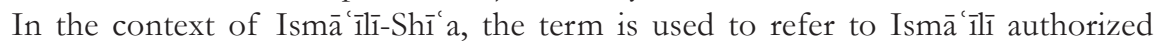
representatives or propagandists who are assigned to carry out a missionary activity (da' wa) of Ismā' îlī understanding of Islam and convert people to Ismā îlilism. See Daftary, The Isma'ilis, p. 515.

${ }^{33} D a^{6} w a$ is the activity that should be carried out by the $d \bar{a}^{6} \bar{i}$, which is to call somebody or a group of people to accept and adopt the Ismā îli religious movement. In this regard, $d a^{6} w a$ can be understood as a mission, propaganda, or missionary activity of the Ismā $\bar{i} l \bar{i} d \bar{a}^{-} i \bar{s}$ to call people to accept the religious and political leadership of the Ismā 'îlì's imàms and to adopt their teachings and doctrines. However, the term da wa is sometimes used to denote the entire hierarchy of ranks within the Ismā 'illi leadership that is made for the purpose of conducting the missionary work. Therefore, the Ismā îli movement itself is often simply called $a l-d a^{6} w a$, or formally al-da' wa al-bädiya (the rightly guided mission). See Ibid.

34 Ibid., p. 111.
35 Ibid., p. 112. 
and started as the chief of Ismā $\overline{1} \mid \overline{1} d \bar{a}^{6} \bar{\imath}$ around 306/918), Muhammad b. Aḥmad al-Nasafî (d. 332/943), and Abū Ya 'qūb al-Sijistānī (d. around 365/975). ${ }^{36}$ Another $d \bar{a}^{6} \bar{\imath}$ that was sent directly from the Fātimids in Egypt to Khurāsān was Nāṣiri Khusraw (d. 481/1088), who according to Farhad Daftary, established his headquarters at Balkh in around 444/1052, from where he extended his da wa activities to Nīshāpūr and other cities of Khurāsān. ${ }^{37}$ Those Ismā 'îlī missionaries not only brought their doctrinal views but also introduced Neoplatonic thought to the Muslim discourse. ${ }^{38}$ For example, inspired by Neoplatonist's cosmology, ${ }^{39}$ al-Sijistānī introduced a concept of tawhìd (unity of God) that denies both anthropomorphist tendency (tashbih) in Islamic theology, which was generally held by Karrāmī, and an extreme anti-anthropomorphist ( $\left.t a^{6} t \underline{t} \bar{i}\right)$ orientation of theology, which was held by Mu'tazilī theologians. In alSijistānī’s thought, God is described as "absolutely transcendent, beyond human comprehension, beyond any name or attribute, beyond being and non-being, and therefore unknowable". ${ }^{40}$ This conception of God not only posed a challenge to theological groups like an anthropomorphist Karrāmīs and non-anthropomorphist $\mathrm{Mu}$ 'tazilī but also to the Ash 'arīs who believed that God can be known rationally through his names and attributes.

Another threat to Sunnī's strength in Nīshāpūr was coming from

36 Ibid., p. 113.

37 Paul Ernest Walker, Early Philosophical Shiism: the Ismaili Neoplatonism of Abu Ya'qub al-Sijistani (Cambridge: Cambridge Univ. Press, 1993), p. 206.

38 Ibid., p. 113. Ibid., p. 224.

39 The core idea of Neoplatonist philosopher, Plotinus, revolves around the concept of three hierarchical elements, which are the One, intellect or mind, and soul. The One is considered ineffable, simple, beyond being and non-being, non-intellective, and beyond rationality. The process of creation starts when the perfection of the One is overflowing and generating a simple being by means of emanation (inbi ${ }^{6} \bar{a} t h$ ), just like the sun and its rays. The first simple being resulted from the emanation of the One is intellect, the universal intellect, and then followed by the second being, which is soul. Below the soul is the physical realm. A man in this hierarchical scheme is not merely a spiritual being because he has a physical element in the forms of body and not only a physical being because he has a spiritual element in the forms of soul. Man possesses both spiritual and physical elements of being. See Walker, Early Philosophical Shiism, pp. 37-8.

40 Daftary, The Isma'ilis, p. 228. 
groups thought to be heretical and mystical. The very early uprising that aimed to shake the stability of religious domination in Nīshāpūr was carried out by a heterodox Zoroastrian leader in Nīshāpūr, Bihafrid-i Mahfravardin from 747 until $749,{ }^{41}$ who came from Zūzan, about 200 kilometers southeast of the city of Nīshāpūr, attempting to syncretize Zoroastrian beliefs with Muslim doctrines. On the one hand, he argued that Zoroastrianism was the true religion and Ohrmazd was the one and the only power in the universe. On the other, he contended that some of Zoroastrian rituals and laws should be changed. Therefore, inspired by Muslim doctrines and practices, he introduced the idea of monotheism, ${ }^{42}$ prophecy, revealed scripture, fixed daily prayers (i.e. seven but can be reduced to five daily prayers), and Zoroastrian's qibla (which is to the left side of the Muslim's qibla) to his new religious movement. ${ }^{43}$ Bihafrid in turn not only challenged Zoroastrian religious establishment in the city of Nīshāpūr, but also threatened Muslim religious and political authority in the region. Abū Muslim al-Khurāsānī (d. 137/755), the charismatic Muslim ruler in the Iranian land at that time, came to Nīshāpūr to squash his movement and kill him. However, his followers still survived in 748 and later on participated in other heretical movements such as Khurramīya. ${ }^{44}$

The other revolt was led by a Magi named Sunpad (or Sinbad, or Sunbādh), who rebelled in $136 / 754^{45}$ and was finally defeated in $137 / 755 .{ }^{46}$ He was not an ordinary villager but the chief (ra'ss) of

41 Choksy, Conflict and cooperation, p. 40.

${ }^{42}$ Bihafrid's monotheism is reflected in the recognition and praise of the unity of Ohrmazd without abandoning Zoroastrian dualistic belief, which is the belief in the power of good and the power of evil. See Patricia Crone, The Nativist Prophets of Early Islamic Iran: Rural Revolt and Local Zoroastrianism (Cambridge: Cambridge University Press, 2012), pp. 147-8.

43 Ibid., pp. 147-9.

${ }^{44}$ Ibid., pp. 150-1. The Khurramīya is a syncretic religious group that has elements of Shīissm and of a Zoroastrian-heretic movement called Mazdakism. Therefore, from a Muslim perspective, Khurramìya is viewed as a branch of Shī a and, from a Zoroastrian perspective, this group is seen as a form of Mazdakism. See Ibid., pp. 279-81.

45 Choksy, Conflict and Cooperation, p. 40.

46 Frye, The Golden Age of Persia, p. 128. 
Nīshāpūr. He hosted Abū Muslim al-Khurāsānī during Abū Muslim’s return to Nīshāpūr as ruler in 748 and eventually joined Abū Muslim's revolutionary movement during that period (748-755). ${ }^{47}$ After the murder of Abū Muslim by the 'Abbāsid caliph al-Manșūr, Sunpad renounced Islam and embraced a new form of Zoroastrianism. According to some sources, Sunpad came to believe in the divinity of Abū Muslim, who, he argued, had not really died but was hiding in "a fortress of brass with the $M a b d i^{48}$ and Mazdak ${ }^{49}$ " and will return one day together with Mazdak as his vizier. ${ }^{50}$ He preached to the Shī îs by telling them about the hidden Mabdi, to the Mazdakians by mentioning the existence of Mazdak, to Khurramīs by convincing them that Mazdak was a Shî ite; and also to his the Zoroastrian followers by saying that the end of Arab rule was predicted in a Sassanian book. ${ }^{51}$ He claimed to be the messenger of Abū Muslim and sought vengeance for him by killing a large number of Muslims until being defeated by the caliph al-Manșūr's commander, Jahwar b. Marār al- 'Ijlī, in $755 .^{52}$

In addition to these religious and military uprisings, there was a powerful heretical local religious movement in Nishāpūr called the Karrāmīya, which was founded by Abū 'Abdullāh Muhammad b. Karrām (d. 255/869). However, better known for their emphasis on mysticism and literalist interpretation of theology so much, their opponents accused them of anthropomorphism. ${ }^{53}$ To spread their doctrines, they

47 Crone, The Nativist Prophets of Early Islamic Iran, p. 32.

48 The Mabdi literally means "the divinely guided one." The Mabdi has been hidden, in occultation, expected to return to the world to restore religious purity and political order.

49 Mazdak is a Zoroastrian magi who implemented ideas of a Zoroastrianheretical ideas of Zardūsht and became the leader of a major revolt in Iraq and western Iran around 531-540. Due to this Mazdak's revolt, the religious group associated with Zardūsht heretical ideas was bettern known as Mazdakism. See Crone, The Nativist Prophets of Early Islamic Iran, pp. 22-3.

50 Ibid., p. 38.

51 The book was probably the astronomical book, The Book of Nativities that had been translated into Arabic by Sa 'īd b. Khurāsān-Khurra in the time of Abū Muslim after Sunpad requested it. Ibid., pp. 34-9.

52 Ibid., pp. 35-6.

53 Malamud, "The Politics of Heresy in Medieval Khurasan", pp. 42-3. 
established khänaqät, centers for education, meeting, and missionary work that by the end of tenth century were adopted by Ṣūfí schools. ${ }^{54}$ Their teachings were initially attractive to the poor who performed menial work in the northwest of the city ${ }^{55}$ but later appealed to both urban and rural populations. In turn, this development was threatening the domination of the Hanafīs and Shāfi $\overline{1}^{\bar{s}}$ in the city. ${ }^{56}$ Furthermore, during the Ghaznavid rule in Nīshāpūr around the end of the tenth century and the early eleventh century, Karrāmī scholars named Abū Ya qūo Isḥāq b. Maḥmadāsh (d. 383/993) and his son Abū Bakr Muḥammad b. Isḥāq were appointed as a chief ( $\left.r a^{\prime} \imath s\right)$ of the city. This appointment incited further enmity from the Hanafī and Shāfi ${ }^{c} \overline{1}$ patricians. ${ }^{57}$

Lastly, the main issue that threatened to destroy the superiority of Sunnī Islam in Nīshāpūr was the prolonged conflict between the Shāfi ìs, who generally happened to be the Ash arīs in theology, ${ }^{58}$ and Hanafis, who generally happened to be Mu'taziliss in theology. ${ }^{59}$ The seeds of

54 Ibid., p. 41.

55 Bulliet, The Patricians of Nishapur, pp. 12-3.

56 Malamud, "The Politics of Heresy in Medieval Khurasan", p. 45.

57 Ibid., pp. 45-6.

58 The Ash 'arī is a theological thought or belief and an individual or a group of people that are associated and affiliated with al-Ash' ariya, which is a theological school founded based on theological teachings of Abū al-Hasan al-Ash 'arī (d. 324/936). This theological school in general advocates traditional understanding of religion such as the uncreatedness of the Qur'an, the acknowledgment of the attributes and names of God, and a more textual interpretation of the Qur'an. However, the school employs rational argument, which was usually used by the rationalist group Mu' tazila, to defend those traditional tenets of religion. See D. Gimaret, "Mu'tazila", Encyclopaedia of Islam, Second Edition (2012), http:/ / referenceworks.brillonline.com/entries/encyclopaedia-ofislam-2/al-ashari-abu-1-hasan-SIM_0780?s.num=8\&s.rows=20\&s.f.s2_parent=s.f.book. encyclopaedia-of-islam-2\&s.q =Abu+\%E2\%80\%99L-\%E1\%B8\%A4asan, accessed 9 Dec 2014. In the context of Nīshāpūr, since the general theological affiliation of the

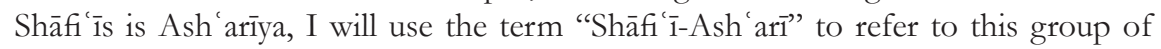
scholars. To understand better the relationship between Shāfi 'i legal school and Ash 'arī theological school in Nīshāpūr, see Bulliet, The Patricians of Nishapur, pp. 36-7.

59 The Mu'tazili is a theological thought or belief and an individual or a group of people that are associated and affiliated with $M u^{6}$ tarila, which is a rationalist theological school and movement founded by Wāṣil b. 'Ațā' (d. 131/748) in Bașra. Among theological doctrines that the $\mathrm{Mu}$ 'tazilī scholars advocate are the createdness of the Qur'an, the absolute oneness of God, and rational interpretation of the Qur'an. 
conflicts were planted sometime around 380/990 when a prominent Shāfi î preacher, 'Abd al-Raḥmān al-Ṣābūnī, was assassinated. ${ }^{60}$ According to Richard Bulliet, it occurred at the same time that "Nīshāpūr became the center of political maneuvering between the ruling Sāmānid dynasty in Bukhara and two subordinate dynasties in Khurāsān, the Simjurids and the Ghaznavids. The legal factions in Nīshāpūr became involved in that political maneuvering and the key posts in the city were often awarded to the faction favoring the dynasty temporarily in power." ${ }^{11}$ The Simjurids backed the Shäfici groups ${ }^{62}$ while the Ghaznavids initially favored the Hanafî but then they also supported the Karrāmìya in Nīshāpūr. ${ }^{63}$ They built an endowed madrasa for the Hanafî Qādī, Abū 'Ala' Ṣā'id, but then appointed the Karrāmī leader, Abū Bakr b. Abū Ya 'qūb, as the ra'šs of the city ${ }^{64}$ This policy upset local religious and political leaders and pressed Maḥmūd of Ghazna to remove Abū Ya 'qūb from the office.

The peak of the dissension, however, occurred in the time of early Saljūq Sultāanate (between 443/1051-447 /1055). 'Amīd al-Mulk alKundurī (d. 456/1064), the vizier of the Saljūq Sulțān Tughril Beg, who in his youth tried to build social mobility through Shāfi ' $\overline{1}$ professional circles, persecuted Shāfi ${ }^{\prime} \overline{1}$ - Ash 'arī groups in that period.

It might be true that al-Kundurī began as a Shāfí $1 \overline{1}$ but since his social mobility was hampered by generational differences within Shāfici circles, he decided to join the Hanafîs ${ }^{65}$ which he did with a view toward helping his social mobility and political career. When Saljūq force came to Nīshāpūr, they established al-Kundurī as vizier. This appointment

They defend these theological tenets through a rational and dialectical arguments inspired mainly by philosophical traditions. See Gimaret, "Mu'tazila". Since the Hanafis in Nīshāpūr generally happen to be affiliated with Mu tazila theology, I will simply call them, the "Hanafi-Mu 'tazilì" scholars. To understand more the relationship between the Hanafis and Mu'tazila theology, see Bulliet, The Patricians of Nishapur, pp. 36-7.

60 Bulliet, The Patricians of Nishapur, p. 32.

61 Ibid.

62 Richard W. Bulliet, "Local Politics in Eastern Iran under the Ghaznavids and Seljuks", Iranian Studies, vol. 11, no. 1-4 (1978), pp. 35-6.

63 Malamud, "The Politics of Heresy in Medieval Khurasan”, pp. 37-51.

${ }^{64}$ Ibid.

65 Martin Nguyen, Sufi Master and Qur'an Scholar: Abul-Qasim al-Qushayr $i$ and the Lata'if al-Ish ar at (Oxford: Oxford University Press, 2012), p. 209. 
was reasonable since the Saljūq Sultạn, who came from Central Asia, was more familiar with the Hanafì rather than the Shäfíi legal school. During his tenure as a vizier, however, al-Kundurī oppressed Shāfi ìAsh 'arī scholars. Abū al-Qāsim al-Qushayrī (d. 465/1072) and Abū alFaḍl Aḥmad al-Furātī (d. 446/1054) were imprisoned. Imām al-Ḥaramayn al-Juwaynī (d. 478/1085) and his fellows were forced into an exile. Abū Sahl al-Muwaffaq (d. 4561064) stayed in Nīshāpūr and went into revolt. ${ }^{66}$

The cause of the persecution is not exactly known. A popular Ash 'arī account maintains that it began when al-Kundurī, who was affiliated with hte Hanafi-Mu'tazili groups, became jealous of the influence of Abū Sahl Muwaffaq, who was, at the age of 17, appointed as the chief of Shāfi'i school of law (madhhab) in Nīshāpūr. He was concerned that Abū Sahl would threaten his position as vizier. ${ }^{67}$ Bulliet has argued that the persecution was based on al-Kundurîs policy of "to divide and conquer". ${ }^{68} \mathrm{Al}-\mathrm{Kundurī} \mathrm{sided} \mathrm{with} \mathrm{the} \mathrm{Hanafi-Mu} \mathrm{'tazilīs} \mathrm{and}$ persecuted the Shāfici-Ash 'arīs. Furthermore, he ordered a condemnation of the Ash arī theological doctrines in Friday sermons, declared a prohibition of their religious and educational sessions, and commanded an arrest of their four prominent scholars as mentioned above (Abū alQāsim al-Qushayrī, Abū al-Fạ̣l Aḥmad al-Furātī, Imām al-Ḥaramayn al-Juwaynī, and Abū Sahl al-Muwaffaq). ${ }^{69}$

\section{Intellectual Networking}

In order to deal with the threats to the Sunnī establishment in Nīshāpūr, the Shāfí̀ $\overline{1}$ and Hanafí scholars enhanced their intellectual credentials by studying and building an intellectual network with members of their schools in other regions, mainly Baghdād and Cairo. They not only acquired legal and theological knowledge from their Baghdādī or

66 Ibid., pp. 40-1.

67 Tāj al-Dīn 'Abd al-Wahhāb ibn 'Alī Subkī, Ṭabaqāt al-Shāfíìyah al-Kubrá, vol. 3, ed. by Maḥmūd Muḥammad and 'Abd al-Fattāḥ Muḥammad al-Ḥalw al-Ṭanāḥī, (Cairo: Maṭbaah 'Īsā al-Bābī al-Halbī, 1967), p. 391. Also see Ismail Haji Abdullah, "The Influence of Imam al-Juwayni on the Theology of Imam al-Ghazali", Ph.D. Dissertation (Scotland: University of St Andrews, 1996), p. 16.

68 Bulliet, The Patricians of Nishapur, p. 72.

69 Subkī, Tabaqāt al-Shājicìyah al-Kubrá, 3: 390-1. 
Cairo teachers but also established intellectual credentials. With these knowledge and credentials, they decided not to stay in Baghdād or Cairo but return to Nīshāpūr and attempt to cope with problems and challenges there.

In the Hanafî intellectual circles, the majority of Hanafì scholars who pursued an academic career in Nīshāpūr were students of Hanafí scholars in Baghdād. These included Abū al-Ḥasan Aḥmad b. Muhammad al-Nīsābūrī Qāệ̄ al-Haramayn (d. 351/962), ${ }^{70}$ Abū Bakr Muhammad b. Aḥmad b. 'Alī al-Shāhawayh al-Fārisī (d. 361/971-2), Abū Bakr Aḥmad b. 'Alī al-Jașsāâs al-Rāzì (d. 370/981), and Abū Sahl al-Zujàjīi al-Ghazālī al-Faraḍi (d. n.d). ${ }^{71}$ As Table I shows, all of them taught law in Nīshāpūr and they were students of Abū al-Hasan al-Karkhī (d. 340/952). ${ }^{72}$

In addition to these scholars, especially from the intellectual lineage of Abū al-Hasan Qāệi al-Haramayn who studied under Abū al-Hasan alKarkhī in Baghdād, some prominent Hanafī figures played a crucial role in Nīshāpūr. Qāọī al-Haramayn had a student named Abū al-Haytham 'Utba b. Khaythama al-Tamīmī (d. 406/ 1015), who used to serve as a judge ( $q \bar{a} d \grave{\imath})$ in Nīshāpūr as well. ${ }^{73}$ One of Abū Haytham's students was Abū al-'Alā’ Șā id b. Muḥammad b. Aḥmad (d. 431/1040), ${ }^{74}$ a very prominent Hanafì scholar in Nīshāpūr. He used to hold a qạdì position as well. His youngest son, Abū Muhammad 'Ubayd Allāh b. Șāa id (d. 486/1093), ${ }^{75}$ became qạdì as well and married to a daughter of another prominent Hạafī scholar, Abū Muḥammad 'Abdullāh al-Nāṣiḥ̄i (d. 447/1055). ${ }^{76}$ Abū Muḥammad 'Ubayd Allāh’s brother-in-law, Abū Bakr Muhammad b. Abū Muhamad 'Abdullāh al-Nāṣihịi (d. 484/1091), was

70 'Abd al-Ghāfir ibn Ismācīl Fārisī, Tārikeh Nìsābūr Al-Muntakhab Min Al-Siyāq (Qum: Jamā'ah al-Mudarrisīn, 1943), p. 117.

71 Melchert, The Formation of the Sunni Schools of Law, 9th-10th Centuries C.E., pp. $126-7$.

72 Ibid., p. 116.

73 'Abd al-Ghāfir al-Fārisī records that Abū al-Haytham studied under Qāḍ̄ al-Haramayn. However, there is a typo in writing Qādī al-Haramayn's name. He writes "Abū al-Husayn," instead of "Abū al-Hasan." The correct one is "Abū al-Hasan" Qāḍī al-Haramayn. See Fārisī, Tārìkh Nìsābūr Al-Muntakhab Min Al-Siyāq, p. 605.

${ }^{74}$ Ibid., pp. 400-1.

75 Ibid., p. 465.

76 Ibid., p. 435; Bulliet, The Patricians of Nishapur, p. 205. 
also a very influential Hanafî figure in Nīshāpūr. ${ }^{77}$

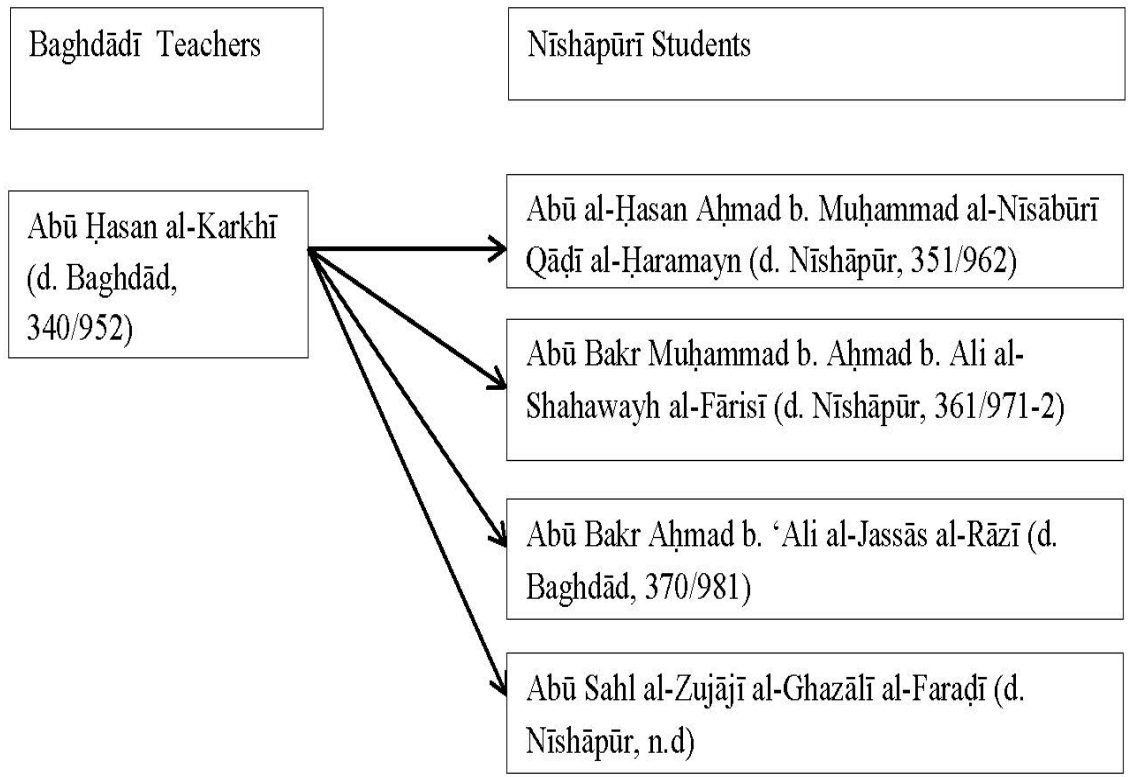

Table 1. The Hanafī Network of Nīshāpūr.

Similarly, the Shāfi'īs of Nìshāpūr are also connected to Baghdādī or Cairo Shāfí ī scholars. The main figure who taught Nīshāpūrī Shāfî̀is was Ibn Surayj (d. Baghdād, 306/918). He was considered the actual consolidator of the Shāficī legal school by modern scholars. ${ }^{78}$ Ibn Surayj and his student, the Egyptian Abū Isḥāq al-Marwazī (d. 340/951), had a number of students from Nīshāpūr. These students then taught and spread Shāfí ${ }^{\prime} \bar{t}$ thought in Nìshāpūr and its surroundings. Among the students of Ibn Surayj were Abū al-Hasan Muhammad b. Shu'ayb b. Ibrāhīm al-Bayhaqī (d. 324/935-6), ${ }^{79}$ Abū al-Ḥasan 'Alī b. al-Hasan b. Muḥammad al-Sanjānī al-Marwazī (d. mid 320s), ${ }^{80}$ and Abū Bakr Aḥmad b. al-Husayn al-Fārisī (d. 350). ${ }^{81}$ Among Abū Isḥāq al-Marwazì’s

\footnotetext{
77 Fārisī, Tärìkh Nìsābūr Al-Muntakhab Min Al-Siyāq, p. 75.

78 Ibid., p. 80.

79 Subkī, Tabaqāt al-Shäfíìyah al-Kubrá, vol. 3, p. 173.

80 Ibid., vol. 3, pp. 444-5.

81 Abū Ishāà al-Shīrāzī, Ṭabaqāt al-Shäfí ìyah (Baghdād: al-Maktabah al-'Arabìyah,
} 1356/1937), p. 23. 
students were Ahmad b. Muhammad al-Ṭabasī (d. 358/968-9), ${ }^{82}$ Abū Sahl al-Ṣu 'ūkī (d. 369/980), ${ }^{83}$ Abū al-Qāsim 'Abd al- 'Azīz b. 'Abdullāh al-Dārakī (d. 375/986), ${ }^{84}$ Abū al-Hasan Muḥammad b. 'Alī al-Sarjisī (d. Nīshāpūr, 384/994), ${ }^{85}$ and Abū 'Alī Muḥammad b. 'Alī al-Balādhurī (d. Nīshāpūr 395/1004). ${ }^{86}$

\begin{tabular}{|l|l|}
\hline Baghdādī/CairoTeachers \\
306/918)
\end{tabular}

82 Subkī, Ṭabaqāt al-Shäfíìyah al-Kubrá, vol. 3, p. 44.

83 Abū Zakarīyā Muhyiddīn b. Sharaf al-Nawawī, Tahdhìb al-Asmā' Wa-al-Lughāt, vol. 1 (Beirut: Dār al-Kutub al-'Ilmīyah, 1977), pp. 241-3; Subkī, Ṭabaqät al-Shäfi'ìyah al-Kubrá, vol. 3, pp. 167-73.

84 Abū Ishāà al-Shīrāzī, Ṭabaqāt al-Shāfí̀yah (Baghdad: al-Maktabah al-'Arabīyah, 1937), p. 31; Subkī, Ṭabaqät al-Shäfíìyah al-Kubrá, vol. 3, pp. 330-3.

85 al-Shīrāzì, Tabaqāt al-Shāfi ìyah, p. 32.

86 Muhammd b. Aḥmad Shams al-Dīn al-Dhahabī, Tãrikh al-Islām, vol. 27, ed. by 'Umar 'Abd al-Salām Tadmūrī (Beirut: Dār al-Kitāb al-'Arabī, 1987), p. 325; alDimashqī Ibn Kathīr, Ṭabaqāt al-Fuqahä al-Shäfi' ìỳn, ed. by Aḥmad 'Umar Hāshim and Muḥammad Z. Muḥammad Gharb (Cairo: Madrasah al-Thaqāfah al-Dīnīyah, 1993), p. 335. See also the description of Abū Ishāq al-Marwazì̄s students in Melchert, The Formation of the Sunni Schools of Law, 9th-10th Centuries C.E., pp. 103-4. 


\section{Table 2. The Shāfi '̄i Network of Nishapur}

Interestingly, one of the greatest Shāfíci scholars in the eleventh century, Imām al-Haramayn al-Juwaynī (419/1028-478/1085), was a Shāfi 'ì intellectual of Ibn Surayj and Abū Isḥāq al-Marwazī. He studied law under his father, Abū Muhammad 'Abdullāh b. Yūsuf al-Juwaynī (d. 438-9/1046-7), and two other teachers, Abū 'Alī Husayn b. Muhammad al-Marwarrūdhī (d. 462/1070) ${ }^{87}$ and Abū Qāsim al-Fūrānī (d. 463/1071) ${ }^{88}$ From these three teachers, his connection with Ibn Surayj and Abū Ishạa al-Marwazì can be traced through two lines of intellectual transmission. First, from his father side, he was connected with Abū Ṭayyib al-Ṣu 'lūkī (d. 404/1013) and Abū Bakr al-Shāshī (d. 417/1026) because his father studied under these two Shāfi 'ì scholars. Abū Țayyib al-Ṣu lūkī and Abū Bakr al-Qaffāl al-Shāshī learned legal knowledge from Abū Sahl al-Ṣu 'lūkī (d. 369/980) and Abū Zayd al-Marwazī (d. 371/982). ${ }^{89}$ The last two scholars studied law under Abū Ishāa al-Marwazī (d. 340/951) and al-Marwazì himself was of the students of Ibn Surayj. Second, from the side of two other teachers (i.e. Abū 'Alī Husayn al-Marw al-Rūdhī and Abū Qāsim al-Fūrānī ), Imām al-Haramayn's lineage was also still connected with Ibn Surayj since the two above teachers studied law under Abū Bakr Muhammad b. 'Alī al-Qaffāl al-Shāshī (366/977), who was in fact one of direct students of Ibn Surayj..$^{90}$

In addition, there were lines of Shāfí̀ intellectual descents in Nīshāpūr that did not originate with Ibn Surayj or al-Marwazī, for instance, 'Abdullāh b. Muḥammad b. Ziyād al-Nīsābūrī (before 164/877) and Ibn Khuzayma were disciples of an earlier generation of Egyptian Shāfi'îs, especially Abū Ibrāhīm Ismā īl b. Yahyā al-Muzanī (d. 264/878) and Abū Muhammad al-Rabī' b. Sulaymān b. 'Abd al-Jabbār al-Murādī (d. 270/884). ${ }^{91}$

${ }^{87}$ Fārisī, Tärìkh Nìsābūr Al-Muntakhab Min Al-Siyāq, p. 305.

88 al-Shīrāzī, Ṭabaqāt al-Shāfi ìyah, p. 56; Abū 'Abbās Shams al-Dīn Aḥmad b. Muhammad b. Abū Bakr Ibn Khallikān, Wafayat al-A'yan wa Anbã' Abna' al-Zamãn, vol. 3, ed. by Iṇsān 'Abbās (Beirut: Dār al-Thaqāfah, 1968), p. 132.

89 al-Nawawī, Tahdhïb al-Asmä' wa-al-Lughät, vol. 1, p. 234.

90 al-Shīrāzī, Țabaqāt al-Shäfíìyah, pp. 56-7; Khallikān, Wafayat al-A'yan wa Anbã' Abna' al-Zamãn, vol. 3, p. 132.

91 al-Shīrāzì, Ṭabaqāt al-Shāfi ìyah, p. 98. 
In addition to the intellectual networking in the field of legal scholarship, the development of Islamic theology shows an analogous connection. The student of Abū al-Hasan al-Ash 'arī (d. 324/936), Abū al-Hasan al-Bāhilī, who was a contemporary of the famous Ash 'arī theologian al-Bāqillānī (d. 403/1013) in Baghdād, taught two Nīshāpūrī Ash ' arī theologian Abū Bakr Muhammad b. Hasan b. Furāk (d. 406/1015) (22 $^{92}$ and Abū Isḥāq Ibrāhīm al-Isfarā'īnī (d.418/1027). ${ }^{93}$ Abū Ishạāq al-Isfarāīnī transmitted the Ash 'arī theological teachings to his student, Abū al-Qāsim 'Abd al-Jabbār al-Iskāf al-Isfarā'īnī (d. 452/1060). ${ }^{94}$ From Abū al-Qāsim, the authority of the Ash 'arī theology was then inherited by his student, Imām al-Ḥaramayn al-Juwaynī (419/1028-478/1085). ${ }^{95}$

92 Fārisī, Tärīkh Nìsābūr al-Muntakhab min al-Siyāq, p. 1; Subkī, Țabaqāt al-Shäfíìyah al-Kubrá, vol. 3, p. 127-35.

93 For a teacher-student relationship between al-Ash 'arī and his students, see Subkī, Tabaqāt al-Shäfíìyah al-Kubrá, vol. 3, p. 369. For the biography of Abū Ishāà al-Isfarā̄ìnī, see al-Nawawī, Tahdhīb al-Asmà' Wa-al-Lughät, vol. 1, p. 225; al-Shīrāzī,

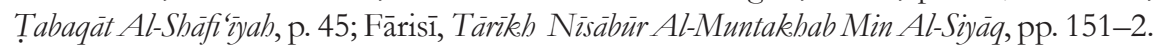

94 al-Fārisīi, p. 522; al-Hāīiz Ibn Kathīr, Ṭabaqāt Al-Fuqabā' Al-Shäfíììn, ed. Anwār al-Bāz, vol. 2 (Egypt: Dār al-Wafā’, 2004), p. 49.

95 Tāj al-Dīn 'Abd al-Wahhāb ibn 'Alī Subkī, Țabaqät al-Shäfí̀ỹah al-Kubrá, vol. 4, ed. by Mạ̣mūd Muḥammad and 'Abd al-Fattāḥ Muḥammad al-Halw al-Ṭanāḥ̄, (Cairo: Mațba'ah 'īsā al-Bābī al-Halbī, 1967), p. 99. 


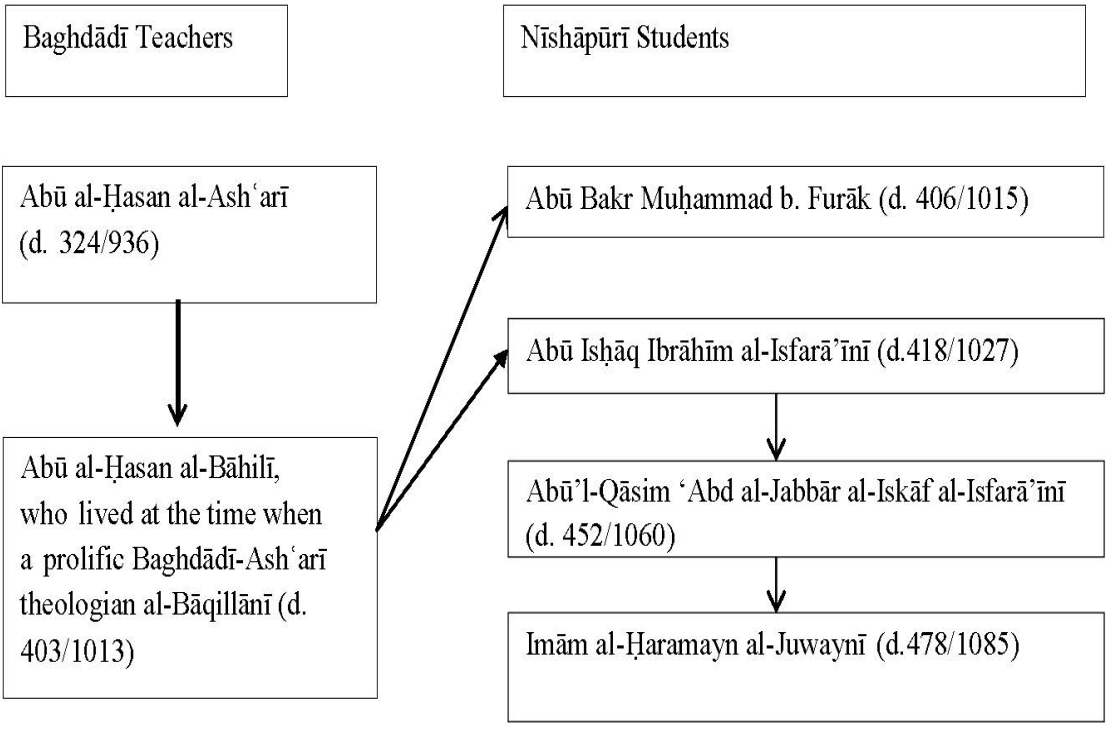

Table 3. The Ash 'arī Network of Nīshāpūr.

The more obvious connection is also apparent in the context of institutions of learning in both cities, especially at the time when Nizām al-Mulk (d. 486/1093) became a vizier of Saljuq Sultānate. He built the madrasa al-Nižămìya in Nīshāpūr in 450/1058, ${ }^{96}$ and then established and completed the building of another madrasa al-Niżămìa in Baghdād in 459/1067. ${ }^{97}$ The inception of these two madrasas, and their affiliates in other cities was initially perhaps based on pious motives (i.e. as a charity for supporting religious scholars and for common good). ${ }^{98}$ However, considering the close relationship between the vizier Niz̄ām al-Mulk and the 'ulama' of those madrasas and prevalent sectarian conflicts in society, it was more evident that the inception of those madrasas was actually to gain a full support and loyalty of religious scholars (ulamā) through

96 Ibid., vol. 4, p. 124.

97 George Makdisi, "Muslim Institutions of Learning in Eleventh-Century Baghdad", in Religion, Law and Learning in Classical Islam (Hampshire: Variorum, 1991), pp. 31-3.

98 See Omid Safi, The Politics of Knowledge in Premodern Islam: Negotiating Ideology and Religious Inquiry (Chapel Hill: The University of North Carolina Press, 2006), p. 95. 
financial and political patronage ${ }^{99}$ and to restore a balance of power in society. ${ }^{100}$ Furthermore, in a larger context, the establishment of those madrasas also helped to enable the Muslim world in the Saljūq territory to be united under Sunnī orthodoxy through a spirit of corps (en sprit de corps) of the Sunnī scholars, who were endowed with administrative and teaching positions in those madrasas. ${ }^{101}$

The madrasa al-Niz̧āmìy in Nīshāpūr was led by Imām al-Haramayn al-Juwaynī and the madrasa al-Niz̧àmīya in Baghdād was led by Abū Isḥāq al-Shīrāzì (d. 476/1083). ${ }^{102}$ Although the curriculum of both madrasas was the same considering both were designed to teach the Shäfi ì legal school, the difference between the two was also apparent. In madrasa al-Nizämìya of Baghdād, the Ash 'arī theology was not really welcomed and promoted since the opposition from external groups, especially Hanbalī scholars, towards Ash arī theology was very strong ${ }^{103}$ that made legal scholars, including Shāfi $\overline{1}$ scholars, afraid of taking and expressing the Ash 'arī theological thoughts. Moreover, most of the teachers were not among

99 George Makdisi, The Rise of Colleges (Edinburgh: Edinburgh University Press, 1981), p. 40.

100 Bulliet, The Patricians of Nishapur, p. 74.

101 Marshall G.S. Hodgson, The Venture of Islam: Conscience and History in a World Civilisation, vol. 2: The Expansion of Islam In The Middle Periods (Chicago: University of Chicago Press, 1974), pp. 47-8; Frye, The Golden Age of Persia, p. 228.

102 The chair position in madrasa Nižàìya of Baghdād was initially offered to Abū Ishāà al-Shīrāzī and he rejected it. The position was then taken by Abū Naṣr b. alSabbādh (d. 477/1084) and he served in the position for about twenty days. The tenure of Abū Nașr was short because Nizāàm al-Mulk kept persuading Abū Ishāa al-Shīrāzī to assume the chair position and finally he accepted it. In the end, Nizām al-Mulk replaced Abū Naṣr b. al-Ṣabbādh with Abū Isḥāq al-Shīrāzī. See Makdisi, "Muslim Institutions of Learning in Eleventh-Century Baghdad", pp. 32-3.

103 When the (Shāfíî̀) Ash 'arī scholar from Nīshāpūr, Abū Naṣr 'Abd alRahīm al-Qushayrī (d. 514/1120), was authorized to speak in madrasa Nižàmȳya around 469/1076 while Abū Ishạā al-Shīrāzī was the chair. The Hanbalīst and other traditionalist group, which were constituted the strongest religious group in Baghdād, opposed Abū Nașr al-Qushayrī because his sermon was mixed with Ash 'arī theological contents. This event triggered a riot in the city that lasted for about two years. And several people were killed. Nizạam al-Mulk finally decided to withdraw Abū Naṣr al-Qushayrī from Baghdād. See Ibid., p. 47; Subkī, Ṭabaqāt al-Shäfíìyah al-Kubrá, vol. 4, pp. 234-5; 'Izz al-Dīn Ibn al-Athīr, The Annals of the Saljuq Turks: Selections from al-Kamil fil-Ta'rikh of Ibn al-Athir, trans. by D.S. Richards (London: Routledge Curzon, 2002), p. 193. 
the Ash 'arīs, including Abū Isḥāq al-Shīrāzī. ${ }^{104}$ Meanwhile, in madrasa al-Nižàmìya of Nīshāpūr, the Ash'arī theology was quiet welcomed and appreciated although it might not be taught formally in madrasa al-Niżämìya. ${ }^{105}$ Some of the Nizammìya's teachers taught Ash 'arī kaläm in their private educational sessions, including the chair of the Nizamiaya, Imām al-Haramayn al-Juwaynī. Some students took an instruction of theology (akhadha 'anbu al-kalām) ${ }^{106}$ directly from Imām al-Haramayn or read his theology book, Kitäb al-Irshäd (qara'a 'alaybi al-Irshäd) in front of him. One of Imām al-Haramayn's most influential students in the field of theology was Muḥammad b. Muḥammad b. Muḥammad b. Aḥmad, al-Ṭūsī, Abū Hāāmid al-Ghazālì (d. 505/1111). ${ }^{107}$

\section{Contextualizing Sunn̄̄ Scholarship in Nīshāpūr}

The intellectual connection with Baghdādī and Cairo scholars might equip Nīshāpūrī scholars with intellectual credentials and knowledge so that they were grounded in the mainstream of Sunnī orthodoxy and tradition. They could use their legal-theological knowledge and credentials

104 Abū Ishāàq al-Shīrāzī was not an Ash 'arī, even used to say that his books on ușül al-fiqh were written to oppose the Ash 'arīs, "These are my books on usül al-fiqh wherein I profess doctrines opposed to those of the Ash 'arīs." See George Makdisi, "The Juridical Theology of Shāfiī: Origins and Significance of Ușūl Al-Fiqh", in Religion, Law and Learning in Classical Islam (Hampshire: Variorum, 1991), p. 29.

105 For example, after being withdrawn from Baghdād, Abū Naṣr al-Qushayrī was welcomed in Nīshāpūr and even assumed a leadership position within Shāfí̀Ash arī circles until he died in 514/1120. He used to study under Imām al-Haramayn al-Juwaynī, the most influential Ash arī scholar in the city and the chair of madrasa al-Niz̧amìya, day and night in a variety of religious sciences. In addition, Tāj al-Dīn Abū al-Fatḥ Muḥammad b. 'Abd al-Karīm al-Shahrastānī (d. 1153) used to study the Ash 'arī theology under al-Nizāmìya's teacher and librarian clerk named Abū al-Qāsim al-Anșārī, who was also a student of Imām al-Haramayn and gave a commentary on the letter's theological book, Kitäb al-Irshäd. See Moufid Nouri, "The Scholars of Nishapur, 700-1225”, Ph.D. Dissertation (Edinburgh: The University of Edinburgh, 1967), pp. 500-2; Fārisī, Tārikeh Nìsābūr al-Muntakhab min al-Siyāq, p. 1069.

106 The term akhadha signifies a private mode of learning, not an institutional mode of leaning, between a teacher and a student. See a further information on this mode of learning in Kevin Jaques, Authority, Conflict, and the Transmission of Diversity in Medieval Islamic Law (Leiden: Brill, 2006), p. 24. Ibid., pp. 123-35.

107 Muḥammad Muṣțafá Zuhaylī, al-Imām al-Juwayni: Imām al-Haramayn (Damascus: Dār al-Qalam, 1986), pp. 84-92. 
that they acquired from Baghdād or Cairo to establish an authority within Shāfi '̀-Ash 'arī or Hanafi-Mu tazilī intellectual circles. However, such a connection only was inadequate in thinking about the challenges and problems that existed in Nīshāpūr.

They needed to contextualize their knowledge and credentials to resist and deal with challenges from other religious groups such as the Ismā ìlīs, Karrāmīs, and local heretical religious movements that were potential to shake the domination of Sunnī (i.e. Shāfi 'ì and Ash 'arî̀) in Nīshāpūr.

The philosophical (neoplatonic) approach to Islamic thought introduced by Ismā îli missionaries required a more rational or rationalized theology and law in order to defend Sunni teachings. The ascetical approaches of the Karrāmìya challenged both the Shāfi 'iss and the Hanafis to provide their own versions of ascetical teachings that did not contradict Sunnī orthodoxy. Meanwhile, the prolonged internal conflict between the Shāfi îs and Hanafìs also forced each of them to establish their adherence to traditional Sunnism and their ability to counter the threats posed by groups such as the Ismāi $1 \bar{l}$ Shî̀ a and the Karrāmìya. Although the influence of Baghdādī and Cairo scholars on their Nīshāpūrī fellows was quite apparent, Nīshāpūrī scholars were, nevertheless, forced to develop their own relatively independent approaches to be more influential than those of their Baghdādī and Cairo teachers. They had to synthesize Islamic legal, theological, and ascetical thoughts in ways that were the direct results of the context of Nīshāpūr's intellectual environment.

In the fifth/eleventh century, the leadership of Hanafi scholarship in Baghdād declined and moved to the east, Khurāsān and Transoxania. ${ }^{108}$ The development of Hanafì legal school in the east, which one of its centers was Nìshāpūr, was to some extents due to the contribution of Hanafī scholars from Nīshāpūr who studied in Baghdād and their intellectual descendants. Abū al- 'Alā' Șā'id, who was an intellectual descendent of Qàdị al-Haramayn, played a crucial role in the development of Hanafì scholarship and defending Sunnī establishment in Nīshāpūr. He utilized his Hanafì credentials and legal knowledge to appeal the

108 Makdisi, "Muslim Institutions of Learning in Eleventh-Century Baghdad", p. 17. 
Ghaznavid ruler to support his educational cause and to confront his religious opponents like Karrāmī leaders. As a result, around the year of 390/1000, the Ghaznavid ruler in Nīshāpūr, Nașr b. Sabuktakīn, founded a madrasa for him to teach primarily Hanafì legal thoughts. The madrasa was named madrasa al-Sa $a^{-6} i d i^{109}$ In addition, when he was accused of being a heretic Mu 'tazilī (which was probably true) by the Karrāmī leader Abū Bakr Muhammad Maḥmashād around 400/1010, he confronted Abū Bakr Muhammad with arguments proving that the Karrāmīs teaching was anthropomorphic. After a long battle in Ghaznavid's court, Abū al- 'Alā' Șā id won and the Karrāmī movement, which was initially supported by Ghaznavid ruler in Nīshāpūr, gradually lost the support and its power was withering away. ${ }^{110}$ After the death of Abū al- 'Alā' in 431/1040, his intellectual and political legacy was continued by his family members, including his son Abū Muhammad 'Ubayd Allāh and the brother of his daughter-in-law, Abū Bakr Muhammad al-Nāṣihị̄, who both used to hold a qạdì position in Nīshāpūr.

However, a more serious and systematic attempt to contextualize intellectual credentials and knowledge that Nīshāpūrī scholars acquired from Baghdādī or Cairo teachers appeared within the community of Shāfi 'ì scholars. The Shāfí $1 \overline{1}$ applied different approaches and strategies to deal with religious and socio-political challenges in Nishāpūr.

First, in order to be able to compete with Hanafi scholars in religious scholarship, some Shāfi '̇̀ scholars who studied with Baghdādī or Cairo teachers in the fourth/tenth century held educational sessions in their private houses, madrasas, mosques, khanaqähs, or stores to teach the Qur'an, hadìth, and Shāfí 'i law. In this period, theology (kaläm) was not commonly taught in Nīshāpūr. For example, Abū Hasan al-Bayhaqī (d. 324/935-6) taught those religious sciences to Shāfi $\overline{1}$ students. ${ }^{111}$ A ḥmad b. Muhammad al-Ṭabasī (d. 358/968-9) stayed for a while in Nīshāpūr to teach and dictate hadith. ${ }^{112}$ Abū Sahl al-Ṣu 'lūkī (d. 369/980) had a

109 Bulliet, The Patricians of Nishapur, pp. 250-1.

110 Ibid., pp. 203-4.

111 Subkī, Tabaqāt al-Shäfíìyah al-Kubrá, vol. 3, p. 173.

112 Ibid., vol. 3, p. 44. 
madrasa ${ }^{113}$ in which he taught figh (Islamic law), convened ḥadith lesson on Friday evenings, and became the head of Shāfi'i scholar community for about 32 years. ${ }^{114}$

This educational activity of Shāfi ${ }^{1} \overline{1}$ scholars continued to run in the fifth/eleventh century. They wanted to ensure that Shāfi 'ì students and young scholars were rooted in the foundational sciences of Islam so that they compete with the Hanafĩ $s$ in the mastery of those traditional sciences (i.e. the Qur'an, hadith, and figh). The son of Abū Sahl al-Ṣu ' lūkī, Abū Ṭayyib al-Ṣu ' lūkī (d. 404/1013), who studied fiqh under his father ${ }^{115}$ continued the teaching activity of his father in the madrasa of al-Ṣu lūkī. He taught several students, including Abū Muhammad al-Juwaynī (d. 438-9/1046-7). ${ }^{116}$ Abū Muhammad al-Juwaynī himself then taught the subject of figh and issued legal opinions at his home. ${ }^{117}$ The son of Abū Muhammad, namely Imām al-Ḥaramayn al-Juwaynī, learned the foundational religious sciences from his father then pursued his own way in knowledge seeking and his own career in teaching and educating Shāfi 'ì scholars. The peak of Imām al-Haramayn's career was when he was appointed as the chief of madrasa al-Nizamiziya by the Saljūq vizier, Nizām al-Mulk (d. 486/1093). In the madrasa, he was responsible to hold educational sessions (primarily on figh) and manage the student affairs for about 30 years. ${ }^{118}$ Furthermore, to ensure that the Shāfi ' 1 students in the madrasa al-Nizamizya grounded more firmly in the science of tradition (ḥadìth), Abū Sahl Muḥammad b. Aḥmad al-Hafṣī al-Marwazī (d. 465/1072) was hired to teach badith. He was considered the most

113 'Abd al-Ghāfir al-Fārisīi indicated that Abū Sahl al-Ṣu 'lūkī had a madrasa when he mentioned that Abū Bakr Muhammad b. Yahyyā al-Muzakkī (d. 474) was buried behind the madrasa of Sahl al-Ṣu 'lūkī. Imām Abū Sa '̄id al-Qushayrī prayed for him in the madrasa of al-Ṣu lūkī as well. See Fārisī, Tärìkh Nìsābür Al-Muntakhab Min Al-Siyāq, p. 61.

114 al-Nawawī, Tahdhīb al-Asmä̀ wa-al-Lughät, vol. 1, pp. 241-3; Subkī, Ṭabaqāt al-Shäfi ìyah al-Kubrá, vol. 3, pp. 167-73.

115 al-Shīrāzì, Ṭabaqāt al-Shäfììyah, pp. 40-1.

116 Ibid., p. 48.

117 Ibid., pp. 48-9.

118 Tāj al-Dīn 'Abd al-Wahhāb ibn 'Alī Subkī, Ṭabaqāt al-Shāfí̀yah al-Kubrá, vol. 5, ed. by Maḥmūd Muḥammad and 'Abd al-Fattāḥ Muḥammad al-Halw al-Ṭanāḥī, (Cairo: Maṭba'ah 'Īsā al-Bābī al-Halbī, 1967), pp. 171-6. 
authoritative scholar of hadith alive at that time because he studied (sami $\left.{ }^{6} a\right)$ hadìth of the Sahịh al-Bukhārī from al-Kushmayhānī (d. 389/998) in Marw, who was a student of Muhammad b. Yūsuf al-Farbarī (d. 320/932) who heard ḥadith directly Imām al-Bukhārī (d. 256/810). ${ }^{119}$

The general tendency of madrasas to teach the foundational subjects (the Qur'an and Hadith) and Shāfi 'ì law was not exclusive to madrasa al-Nižàmìya. This also applied to other Shāfi' $\overline{1}$ as well madrasas such as the madrasa of Ibn Fūrak, madrasa of Abū Ishāa al-Isfarāìnī, and madrasa al-Baybaqi. ${ }^{120}$ The only exception was probably the madrasa al-Bayhaqi to which Imām al-Haramayn al-Juwaynī went to study not only legal theory (usūl al-fiqh) but also principles of theology (usülal-dinn) under Abū al-Qāsim al-Iskāf al-Isfarā'̄in̄i. ${ }^{121}$ In other words, the subject of theology was also offered in the madrasa al-Bayhaqi. However, the main subjects taught in the madrasas were foundational subjects and Shāfi 'ì school of law. Teaching these subjects enabled Shāfi 'i scholars and students to compete and deal with other legal schools, especially the Hanafi legal school, because knowledge and competence in those subjects could make them more confident that they were more grounded in Sunnī orthodoxy than their opponents.

Second, in addition to the formal educational session in the madrasas, the Shāfi ' $\overline{1}$ teachers also gave an instruction of the Ash 'arī kalam their private educational sessions. This instruction mainly aimed to equip Shāfi 'i scholars with a necessary tool to resist their theological opponents such as the Karrāmī, Mu 'tazilī, or Ismā 'îlī theologians. Imām Abū al-Qāsim 'Abd al-Karìm al-Qushayrī (d. 465/1072), one of the most prominent Șūfis in Nīshāpūr, took an instruction in the discipline of theology (akhadha 'ilm al-kaläm) from Ibn Fūrak. ${ }^{122}$ Interestingly, the word

119 Fārisī, Tärikhh Nìsābür al-Muntakhab min al-Siyāq, p. 65; Bulliet, The Patricians of Nishapur, p. 57.

120 See the list of madrasas in Nīshāpūr made by Richard Bulliet in Bulliet, The Patricians of Nishapur, pp. 249-55.

121 See Jamāl al-Dīn 'Abd al-Rahīm b. al-Ḥasan al-Isnawī, Ṭabaqāt al-Shäfíȳyah, ed. by 'Abdullāh al-Jabūrī (Baghdād: Ri'āsat Dīwān al-Awqāf, 1970), p. 91; Taqī al-Dīn Abū Bakr b. Aḥmad Ibn Qāẹī Shuhbah, Ṭabaqāt Aa-Fuqahā’ al-Shāfí̀ìah, vol. 1, ed. by Muḥammad 'Umar 'Alī (Cairo: Maktabah al-Thaqāfah al-Dīnīyah, 1990), p. 237.

122 Subkī, Ṭabaqàt al-Shäfí̀yah al-Kubrá, vol. 4, p. 154. In the footnote of the book Tärikh Nisäbür al-Muntakhab min al-Siyāq of 'Abd al-Ghāfir al-Fārisī, based on various 
akbadha (to take an instruction) seemed to denote an informal or private mode of learning. ${ }^{123}$ Moreover, as mentioned earlier, Imām Haramayn al-Juwaynī mastered (basșala) discipline of theology from his teacher, Abū al-Qāsim al-Iskāf al-Isfarā̄̄n̄i, when we studied in the madrasa al-Bayhaqi. ${ }^{124}$ In addition, when he was there, he had an opportunity to read theological works of the reputable Ash arī theologian, Abū Bakr al-Bāqillānī (d. 403/1013) outside al-Isfarā'inî̀'s sessions. ${ }^{125}$ He used to reflect on this moment, "I do not say a word in kaläm until I memorized twelve thousand pages of the kalām of Abū Bakr al-Bāqillānì”. ${ }^{126}$ Imām al-Haramayn al-Juwaynī not only studied Ash arī theology from his teachers, he also taught this subject in a private mode of learning outside madrasa al-Nižamiya's sessions. He taught kalam among others to Abū Sa 'd b. Abū Șāliḥ al-Mu’dhdhin (d. 532/1137), Abū al-Qāsim al-Anșārī (d. 512/1118), and Abū Hāmid al-Ghazālī (d. 505/1111). ${ }^{127}$ The underlying important question with regard to the phenomena of Shāfi ' $\overline{1}$ scholars teaching theology is that, why did they need to bring and teach the subject of theology?

In this regard, the story of Ibn Fürak of why he studied the discipline of kalam is the best illustration. He said, "I was in Iṣbahān

sources, the editor mentioned that al-Qushayrī read to Ibn Fūrak until he mastered (qara'a 'alaybi hattà atqana) the discipline of ușül. The term ușül here referred to the theology of Ash 'arī because in the last line, the editor quoted al-Khațīb al-Baghdādī saying, "He (alQushayrī) knows al-ușül (principle of theology, or usūul al-dīn) in the school of al-Ash 'arī and knows fur $\bar{u}^{-}$(branches of religion, or fiqh) in the school of al-Shāfi 'i..” In addition, al-Qushayrī also frequently attended the session of Abū Isḥāq al-Isfarā'̄n̄ì to listen to his lesson ( $q a^{6} a d a$ li-yasma'a darsabu) on al-usül (Ash 'arī theology). From the term used to denote the mode of learning between al-Qushayrī and Abū Ishā̄ al-Isfarāīnī (since the word dars was used in the phrase "qa" ada li yasma" a darsabu"), there was a possibility that the session was conducted in madrasa of al-Isfarä'min. See Fārisī, Tärikeh Nisäaür al-Muntakhab min al-Siyàq, pp. 512-3 Footnote No. 1104.

123 See Jaques. Although Jaques studied the use of different modes of learning, including akhadha, in the context of Tabaqät of Ibn Shuhba, it also applies to other Tabaqāt works, including the Tabaqāt of al-Subkī.

124 See also Subkī, Ṭabaqāt al-Shäfíìyah al-Kubrá, vol. 5, pp. 169-70.

125 Mohammad Moslem Adel Saflo, Al-Juwayni’s Thougth and Methodology with a Translation and Commentary on Luma' al-Adillah (Berlin: Klaus Schwarz Verlag, 2000), p. 19.

126 Zuhaylī, al-Imām al-Juwaynì, p. 60.

127 Zuhaylī, al-Imām al-juwaynì, pp. 84-92. 
and paid a visit to a jurist. I heard a statement saying that "the (black) stone (in the $\mathrm{Ka}$ 'ba) is Allah's right hand on earth (anna al-hajara yamin Alläh fi al-ard). "I asked the meaning of that statement to the jurist. Unfortunately, he did not give a satisfying answer. Then I was advised to go to a scholar of theology. Then I asked the same question and he gave a satisfying answer. Then I said to myself that I had to know this knowledge. Then I studied kaläm." 128 In the case of Ibn Fūrak, this story was an illustration of the insufficiency of legal discipline (figh) to answer theological questions that made him go to study theology. The study of kalam was even necessary because he faced a formidable theological opponent from Abū 'Abdullāh b. Karrām and his Karrāmī students. ${ }^{129}$ In order to meet their theological claims and challenges, Ibn Fūrak needed to master the discipline of theology.

The reason of the insufficiency of fiqh seemed to be applicable to other Shāfí 'ì scholars who studied and taught Ash 'arī theology in Nīshāpūr in the late fourth/tenth and early fifth/eleventh century, like Abū Isḥāq al-Isfarāīnī, Abū Qāsim al-Isfarā'īnī, and Imām al-Haramayn al-Juwaynī. By mastering Ash 'arī kalām, Shāfi '̀̄ scholars aimed to be able to refute their theological adversaries. Imām al-Haramayn al-Juwaynī, for instance, employed his knowledge of theology to refute not only Karrāmī and $\mathrm{Mu}$ 'tazili theologians, but also Ismā ${ }^{\mathrm{i}} \mid \mathrm{l}^{130}$ theologians through his book Kitäb al-Irshäd. ${ }^{131}$

Third, in addition to challenges from fellow legal scholars and theological opponents, Sunnī scholars in Nīshāpūr also had to deal with mystical groups and individuals that taught mystical and ascetical aspects of Islam, like Karrāmī scholars and Abū Sa '̄id b. Abì al-Khayr (d. 440/1049), who taught an ecstatic form of tasamnuf (Islamic mysticism). ${ }^{132}$ To response to this kind of challenge, Shāfi ' $\overline{1}$ scholars represented by

128 Subkī, Ṭabaqät al-Shäfíìyah al-Kubrá vol. 4, p. 129.

129 Ibid., p. 130.

${ }^{130}$ Imām al-Haramayn used the term Bāṭinìya to refer to the Ismā îllì group.

131 'Abd al-Malik ibn 'Abd Allāh Imām al-Haramayn al-Juwaynī, Kitāb al-Irshāed ilá qawātic al-adillah fì ușül al-ítiqāad, ed. by Muhammad Yūsuf and 'Alī 'Abd al-Mun'im 'Abd al-Hamīd Mūsa (Cairo: Maṭba'a al-Sa'āda, 1950), p. 37.

132 See a brief discussion about Abū Sa '̄ìd b. Abī al-Khayr and his ecstatic form of Sufism in Nguyen, Sufi Master and Qur'an Scholar, pp. 74-5; Bulliet, Islam, p. 157. 
Abū Qāsim 'Abd al-Karīm al-Qushayrī studied and taught Sufism that did not deviate from Sunnī orthodoxy. ${ }^{133}$ Furthermore, although Imām alHaramayn's tasawnuf works and students were unknown, he was reported to have practiced and taught this spiritual aspect of Islam. ${ }^{134}$ In other words, the spiritual practice and teaching of the Sunnī scholars, especially reflected by the Shāfi iss, functioned, among other things, to resist mystical and ascetical practices and teachings of their opponents in Nīshāpūr.

\section{E. Concluding Remarks}

Nīshāpūr as one of major cities in eastern Muslim world provided both challenges and opportunities for Sunnī scholars in the tenth/ eleventh century. They were encountered with heretical religious movements, oppositions from different legal and theological groups, and challenges from mystical groups and individuals that threatened Sunnī establishment in Nīshāpūr.

In order to deal with these problems and challenges, Sunnī scholars took two main strategies. First, they made an intellectual networking with a larger Sunnī scholarship in Baghdād, Cairo, or other cities, like Marw, where Sunnī teachers who had a connection with Baghdādī or Cairo teachers resided. This networking gave them necessary knowledge and credentials in Sunnī scholarship. Second, the Sunnī scholars contextualized the knowledge and intellectual credential that they acquired from their teachers to respond and deal with problems and challenges in Nīshāpūr. There were three ways of contextualizing their knowledge and credentials. First, the Sunnī scholars, both the Hanafìs and Shāfi 'îs, were competing to be more grounded in the traditional and legal scholarship by teaching the students the Qur'an, hadith, and legal knowledge in their madrasas, mosques, or private houses. Second, they adopted the discipline of theology and taught them in their educational sessions. This phenomenon especially appeared within the Shāfi ${ }^{\prime} \overline{1}$ intellectual community. They needed to master the discipline of theology (kaläm) in order to refute their theological opponents, ranging from Karrāmī,

133 'Abd al-Karīm ibn Hawāzin Qushayrī, Al-Risala al-Qushayriyya Fi 'ilm alTasanmuf (Cairo: Maktaba wa Mațba'a Muḥammad 'Alī Ṣabịh wa Awlāduh, 1966), p. 51. 134 Subkī, Ṭabaqāt al-Shāfí̀ìah al-Kubrá vol. 5, p. 180; al-Shīrāzī, Ṭabaqāt AlShäficiyah, pp. 61-2. 
Mohammad Syifa Amin Widigdo

Mu 'tazila, to Ismā '̂̀ $1 \overline{1}$ theologians. Third, the Sunnī scholars, especially the Shāfi 'is, also developed a distinct mystical teaching that was different from what had been available in Nīshāpūr at that time. Their mystic and ascetical teaching was considered not deviating from Sunnī orthodoxy as opposed to ecstatic mysticism of Ibn Abī al-Khayr or anthropomorphic asceticism of Karrāmī scholars. 


\section{BIBLIOGRAPHY}

Abdullah, Ismail Haji, "The Influence of Imam al-Juwayni on the Theology of Imam al-Ghazali”, Ph.D. Dissertation, Scotland: University of St Andrews, 1996.

al-Athìr, 'Izz al-Dīn Ibn, The Annals of the Salinq Turks: Selections from al-Kamil fil-Ta'rikh of Ibn al-Athir, trans. by D.S. Richards, London: RoutledeCurzon, 2002.

Bosworth, C.E., "The Political and Dynastic History of the Iranian World (A.D. 1000-1217)", in The Cambridge History of Iran, vol. 5: The Saljuq and Mongol Periods, ed. by J.A. Boyle, Cambridge: Cambridge University Press, 1968.

----, "The Rise of the Karrāmìyah in Khurasan", in The Medieval History of Iran, Afghanistan, and Central Asia, ed. by C.E. Bosworth, London: Variorum Reprint, 1977.

Bulliet, Richard W., The Patricians of Nishapur: A Study in Medieval Islamic Social History, Cambridge: Harvard University Press, 1972.

Bulliet, Richard W., "Local Politics in Eastern Iran under the Ghaznavids and Seljuks", Iranian Studies, vol. 11, no. 1-4, 1978, pp. 35-56 [http:// dx.doi.org/10.1080/00210867808701539].

Bulliet, Richard W., Islam: The View From the Edge, New York: Columbia University Press, 1994.

Busse, Heribert, "Iran under the Būyids", in The Cambridge History of Iran, vol. 4: The Period from the Arab Invasion to the Saljuqs, ed. by Richard N. Frye, Cambridge: Cambridge University Press, 1975.

Choksy, Jamsheed K., Conflict and Cooperation: Zoroastrian Subalterns and Muslim Elites in Medieval Iranian Society, New York: Columbia University Press, 1997.

Crone, Patricia, The Nativist Prophets of Early Islamic Iran: Rural Revolt and Local Zoroastrianism, Cambridge: Cambridge University Press, 2012.

Daftary, Farhad, The Isma'ilis: Their History and Doctrines, Cambridge: Cambridge University Press, 2007.

al-Dhahabī, Muhammd b. Aḥmad Shams al-Dīn, Tärïkh al-Islām, vol. 27, ed. by 'Umar 'Abd al-Salām Tadmūrī, Beirut: Dār al-Kitāb al-'Arabī, 
Mohammad Syifa Amin Widigdo

1987.

Fārisī, 'Abd al-Ghāfir ibn Ismāīil, Tārikeh Nìsābūr al-Muntakhab Min alSiyàq, Qum: Jamā'ah al-Mudarrisīn, 1943.

Fierro, Ma. Isabel (ed.), Orthodoxy and Heresy in Islam, Abingdon, Oxon; N.Y.: Routledge, 2014.

Frye, Richard N., The Golden Age of Persia, New York: Barnes \& Noble Books, 1975.

Gimaret, D., "Mu'tazila", Encyclopaedia of Islam, Second Edition, 2012, http://referenceworks.brillonline.com/entries/encyclopaediaof-islam-2/al-ashari-abu-1-hasan-SIM_0780?s.num $=8 \&$ s. rows $=20 \&$ s.f.s2_parent $=$ s.f.book.encyclopaedia-of-islam-2\&s. $\mathrm{q}=\mathrm{Abu}+\% \mathrm{E} 2 \% 80 \% 99 \mathrm{~L}-\% \mathrm{E} 1 \%$ B8\%A4asan, accessed 9 Dec 2014.

Hodgson, Marshall G.S., The Venture of Islam: Conscience and History in a World Civilisation, vol. 1: The Classical Age of Islam, Chicago: University of Chicago Press, 1974.

----, The Venture of Islam: Conscience and History in a World Civilisation, vol. 2: The Expansion of Islam In The Middle Periods, Chicago: University of Chicago Press, 1974.

al-Isnawī, Jamāl al-Dīn 'Abd al-Rahịm b. al-Hasan, Ṭabaqāt al-Shāfi'ìyah, ed. by 'Abdullāh al-Jabūrī, Baghdād: Ri'āsat Dīwān al-Awqāf, 1970.

Jaques, Kevin, Authority, Conflict, and the Transmission of Diversity in Medieval Islamic Law, Leiden: Brill, 2006.

al-Juwaynī, 'Abd al-Malik ibn 'Abd Allāh Imām al-Haramayn, Kitāb alIrshād ilá qawātic al-adillah fì ușūl al-i'tiqād, ed. by Muhammad Yūsuf and 'Alī 'Abd al-Mun 'im 'Abd al-Hamīd Mūsa, Cairo: Maṭba a al-Sa'āda, 1950.

Kathīr, al-Dimashqī Ibn, Tabaqāt al-Fuqahä’ al-Shäfíìin, ed. by Aḥmad 'Umar Hāshim and Mụ̣ammad Z. Muḥammad Gharb, Cairo: Madrasah al-Thaqāfah al-Dīnīyah, 1993.

Khallikān, Abū 'Abbās Shams al-Dīn Aḥmad b. Muhammad b. Abū Bakr Ibn, Wafayat al-A'yan wa Anbã' Abna' al-Zamãn, vol. 3, ed. by Ihsān 'Abbās, Beirut: Dār al-Thaqāfah, 1968.

Kroger, Jens, Nishapur: Glass of the Early Islamic Period, New York: Metropolitan Museum of Art, 1995. 
Makdisi, George, The Rise of Colleges, Edinburgh: Edinburgh University Press, 1981.

----, "Muslim Institutions of Learning in Eleventh-Century Baghdad", in Religion, Law and Learning in Classical Islam, Hampshire: Variorum, 1991.

----, “The Juridical Theology of Shāfi 'ì: Origins and Significance of Uṣūl Al-Fiqh", in Religion, Law and Learning in Classical Islam, Hampshire: Variorum, 1991.

----, "The Sunnī Revival”, in History and Politics in Eleventh-Century Baghdad, ed. by George Makdisi, London: Variorum, 2010.

Malamud, Margaret, "The Politics of Heresy in Medieval Khurasan: The Karramiyya in Nishapur", Iranian Studies, vol. 27, no. 1/4, 1994, pp. 37-51.

Martin, Richard C., Islamic Studies: A History of Religions Approach, New Jersey: Prentice Hall, 1996.

Martin, Richard C. and Abbas Barzegar, "Formations of Orthodoxy", in Rethinking Islamic Studies: From Orientalism to Cosmopolitanism Bruce B. Lawrence:, ed. by Carl W. Ernst and Richard C. Martin, South Carolina: University of South Carolina Press, 2010.

Massignon, Louis, "Mutanabbi, devant le Siècle Ismaelien de l'Islam", in Al Mutanabbi. Recueil Publié a l'Occasion de son Millénaire, Beirut: Institut Francais de Damas, 1936.

Melchert, Christopher, The Formation of the Sunni Schools of Law, 9th-10th Centuries C.E., Leiden: E.J. Brill, 1997.

Momen, Moojan, An Introduction to Shic Islam: The History and Doctrines of Twelver Shi'ism, New Haven: Yale University Press, 1987.

Morgan, David, Medieval Persia 1040-1797, London: Pearson Education Limited, 1988.

al-Nawawī, Abū Zakarīyā Muhyiddīn b. Sharaf, Tahdhïb al-Asmä’ Wa-alLughät, vol. 1, Beirut: Dār al-Kutub al-'Ilmìyah, 1977.

Nguyen, Martin, Sufi Master and Qur'an Scholar: Ab ul-Qasim al-Qushayr i and the Lata'if al-Ish ar at, Oxford: Oxford University Press, 2012.

Nouri, Moufid, “The Scholars of Nishapur, 700-1225”, Ph.D. Dissertation, Edinburgh: The University of Edinburgh, 1967. 
Qushayrī, 'Abd al-Karīm ibn Hawāzin, Al-Risala al-Qushayriyya Fi 'ilm al-Tasawwuf, Cairo: Maktaba wa Maṭba a Muḥammad 'Alī Șabīḥ wa Awlāduh, 1966.

Richard W. Bulliet, Conversion to Islam in the Medieval Period, Cambridge: Harvard Univ Press, 1979.

Safi, Omid, The Politics of Knowledge in Premodern Islam: Negotiating Ideology and Religious Inquiry, Chapel Hill: The University of North Carolina Press, 2006.

Saflo, Mohammad Moslem Adel, Al-Juwaynis Thougth and Methodology with a Translation and Commentary on Luma' al-Adillah, Berlin: Klaus Schwarz Verlag, 2000.

al-Shīrāzī, Abū Ishāā, Ṭabaqāt al-Shāfícìyah, Baghdad: al-Maktabah al'Arabìyah, 1937.

Shuhbah, Taqī al-Dīn Abū Bakr b. Aḥmad Ibn Qāẹī, Tabaqāt al-Fuqahä' al-Shäfí iỹah, vol. 1, ed. by Muhammad 'Umar 'Alī, Cairo: Maktabah al-Thaqāfah al-Dīnīyah, 1990.

Subkī, Tāj al-Dīn 'Abd al-Wahhāb ibn 'Alī, Ṭabaqāt al-Shāêi ìyah al-Kubrá, vol. 3, ed. by Maḥmūd Muhammad and 'Abd al-Fattāḥ Muhammad al-Halw al-Ṭanāḥī, Cairo: Maṭba' ah 'Īsā al-Bābī al-Halbī, 1967.

----, Ṭabaqāt al-Shäfíyah al-Kubrá, vol. 4, ed. by Maḥmūd Muhammad and 'Abd al-Fattāḥ Muhạmmad al-Halw al-Ṭanāḥī, Cairo: Maṭba 'ah 'İsā al-Bābī al-Halbī, 1967.

----, Ṭabaqāt al-Shäfí̀yah al-Kubrá, vol. 5, ed. by Maḥmūd Muhammad and 'Abd al-Fattāh Muhammad al-Halw al-Ṭanāhị, Cairo: Maṭba 'ah 'Īsā al-Bābī al-Halbī, 1967.

Walbridge, John, God and Logic in Islam the Caliphate of Reason, Cambridge: Cambridge University Press, 2011.

Walker, Paul Ernest, Early Philosophical Shiism: The Ismaili Neoplatonism of Abu Ya'qub al-Sijistani, Cambridge: Cambridge Univ. Press, 1993.

Wilkinson, Charles K., Nishapur: Some Early Islamic Buildings and Their Decoration, New York: Metropolitan Museum of Art, 1986.

Zuḥaylī, Muḥammad Muștafá., al-Imām al-Juwayni: Imām al-Haramayn, Damascus: Dār al-Qalam, 1986. 